\title{
Induction of inflammatory cytokines by a soluble moiety prepared from an enzyme lysate of Actinomyces viscosus cell walls
}

\author{
H. TAKADA*, S. KIMURA $\dagger$ and S. HAMADA $\ddagger$ \\ Department of Oral Microbiology, Osaka University Faculty of Dentistry, 1-8 Yamadaoka, Suita-Osaka, 565 Japan
}

\begin{abstract}
Summary. A carbohydrate-rich and immunobiologically active component, M1Av, was prepared from an M-1 endo- $N$-acetylmuramidase digest of cell walls of Actinomyces viscosus ATCC 19246 by CM Sephadex C- 25 and Sephadex G-100 chromatography. M1Av stimulated thioglycolate-induced peritoneal macrophages from $\mathrm{C} 3 \mathrm{H} / \mathrm{HeN}$ and $\mathrm{C} 3 \mathrm{H} / \mathrm{HeJ}$ mice to release cell-free tumour necrosis factor (TNF) and interleukin (IL)-6, and a cell-associated thymocyte activating factor, probably IL-1. An intravenous (i.v.) injection of M1Av induced increased levels of TNF and IL- 6 in the serum of $\mathrm{C} 3 \mathrm{H} / \mathrm{HeN}$ mice that had been primed with $100 \mu \mathrm{g}$ of muramyldipeptide (MDP) i.v. However, M1Av did not induce TNF release in $\mathrm{C} 3 \mathrm{H} / \mathrm{HeJ}$ mice similarly primed with MDP. Simultaneous administration of M1Av $(100 \mu \mathrm{g}$, i.v.) and galactosamine ( $18 \mathrm{mg}$, intraperitoneally) killed $\mathrm{C} 3 \mathrm{H} / \mathrm{HeN}$, but not $\mathrm{C} 3 \mathrm{H} / \mathrm{HeJ}$ mice. M1Av was shown to be practically free of endotoxin by the Limulus test. These findings indicate that the solubilised $A$. viscosus cell-wall carbohydrate moiety induced inflammatory cytokines both in vitro and in vivo.
\end{abstract}

\section{Introduction}

Actinomyces species are filamentous, gram-positive bacteria, and Actinomyces viscosus and A. naeslundii are important members of human dental plaque flora that have been implicated in the development of gingivitis and the early phase of periodontitis. ${ }^{1-3}$ Increased levels of serum IgG or IgM specific for $A$. viscosus have been found in human subjects and rats who harboured $A$. viscosus in their oral cavity. ${ }^{4,5}$ Sonic lysates of $A$. viscosus whole cells exhibit mitogenic and adjuvant activities in lymphoid cells and polyclonal $B$ cell activation..$^{6-8}$ Furthermore, these cellular fractions from $A$. viscosus showed cytostatic or cytotoxic effects on lymphocytes and fibroblasts. The specific factors responsible for these activities remain to be elucidated. ${ }^{9,10}$ A water-soluble, carbohydrate-rich moiety was isolated from digests of purified cell walls of $A$. viscosus ATCC 19246 that had been treated with a cellwall lytic enzyme, M-1 endo- $N$-acetylmuramidase (M1 enzyme); it was designated M1Av. ${ }^{11}$ This was serologically active, formed a precipitin band with antiserum to $A$. viscosus whole cells and exhibited B cell mitogenicity and polyclonal $\mathrm{B}$ cell activation in murine

Received 23 July 1992; revised version accepted 13 Oct. 1992. *Present address: Department of Oral Microbiology, Kagoshima University Dental School, 8-35-1 Sakuragaoka, Kagoshima, 890 Japan.

†Present address: Department of Periodontics, Fukuoka Dental College, $700 \mathrm{Ta}$, Sawara-ku, Fukuoka, 814-01 Japan. $\ddagger$ Correspondence should be sent to Professor S. Hamada. lymphoid cell cultures. ${ }^{12}$ Bacterial components generally activate macrophages to induce cytokines such as interleukin (IL)-1, IL-6, IL-8 and tumour necrosis factor (TNF), that are involved in inflammatory and immunological reactions in the host. These cytokines are produced by various host cells, and diffuse locally or are transported systemically to regulate the functions of other host cells, including the central nervous and endocrine systems. This cytokine network is activated during inflammation, injury, healing and microbial infections. ${ }^{13}$

Therefore, we examined whether M1Av induces inflammatory cytokines in murine macrophage cultures and in mice treated with muramyldipeptide (MDP).

\section{Materials and methods}

\section{Preparation of MIAv}

M1Av was prepared from M1 endo- $N$-acetylmuramidase digests of cell walls of $A$. viscosus ATCC 19246 as described previously. ${ }^{11}$ Briefly, lyophilised cells of $A$. viscosus were disrupted mechanically, treated with pronase and trypsin, followed by differential centrifugation to isolate purified cell walls. The cell walls were degraded with M-1 enzyme and the lysate was chromatographed on a CM Sephadex C-25 column $(5.3 \times 50 \mathrm{~cm})$ to remove the M1 enzyme. The non-adsorbed material was applied to a Sephadex G100 column $(5 \cdot 3 \times 100 \mathrm{~cm})$. The major peak fraction 
that reacted with rabbit antiserum to $A$. viscosus whole cells was collected, dialysed and lyophilised. This was designated M1Av and its mol. wt was calculated to be $35000-40000 .{ }^{12}$ Chemical analysis showed that M1Av consisted of carbohydrate $75 \%$-the major components of which were 6-deoxytalose, rhamnose and galactose - and protein $23 \%$. The endotoxin content in M1Av was $c .14 .6 \mathrm{ng} / \mathrm{mg}$ based upon the results of the Endospecy Test (Seikagaku Kogyo Co., Tokyo, Japan), which is a colorimetric Limulus test. ${ }^{14}$

\section{Biochemical standards}

A purified lipopolysaccharide (LPS) preparation from Salmonella abortus-equi (Novo-Pyrexal) ${ }^{15}$ was kindly supplied by C. Galanos (Max-Planck Institut für Immunbiologie, Freiburg, Germany) and was used as a reference standard in most of the experiments. In the Endospecy and lethal toxicity test, LPS of Escherichia coli O111:B4, prepared by hot phenol-water extraction (Difco) was used as the reference LPS. MDP was a gift from Daiichi Pharmaceutical Co., Tokyo. Recombinant human IL-6 (rHuIL-6; $5 \times 10^{6} \mathrm{U} / \mathrm{mg}$ of protein) was generously supplied by Drs T. Kishimoto and T. Hirano, Osaka University Medical School, Suita-Osaka, Japan.

\section{Mice}

Both male and female $\mathrm{C} 3 \mathrm{H} / \mathrm{HeN}$ and $\mathrm{C} 3 \mathrm{H} / \mathrm{HeJ}$ mice (6-12 weeks old; CLEA Japan Co., Osaka, Japan) were used for in-vivo assays and macrophage preparation. $\mathrm{C} 3 \mathrm{H} / \mathrm{HeJ}$ mice were also bred and maintained in the animal facility of Osaka University Faculty of Dentistry. Thymocyte activating factor (TAF) was assayed in thymocytes from 3-5-week-old $\mathrm{C} 3 \mathrm{H} / \mathrm{HeJ}$ mice.

\section{Macrophage culture}

Peritoneal exudate macrophages were collected from mice that had received $1.5 \mathrm{ml}$ of Thioglycolate Medium (Nissui Seiyaku Co., Tokyo) intraperitoneally (i.p.); $100-\mu$ l volumes of the cell suspensions $\left(10^{6} / \mathrm{ml}\right)$ in RPMI 1640 medium were distributed into flat-bottomed microculture plates (Corning 25860; Corning Glass Works, Corning, NY, USA). After incubation in an atmosphere of $\mathrm{CO}_{2} 5 \%$ in air at $37^{\circ} \mathrm{C}$ for $2 \mathrm{~h}$, non-adherent cells were removed from the plate. Adherent cells were cultured with test specimens in triplicate in $100 \mu \mathrm{l}$ of RPMI 1640 for $24 \mathrm{~h}$. The culture supernates were pooled for cell-free TNF, IL6 and TAF assays. Adherent cells were washed, and after the addition of $100 \mu \mathrm{l}$ of RPMI 1640, were then fractured by freezing at $-80^{\circ} \mathrm{C}$ and thawing at $25^{\circ} \mathrm{C}$ three times. Cell-associated TAF activity was measured in the fractured cell suspensions.

\section{Cytokine assays}

$T N F$. For TNF assay, $100 \mu \mathrm{l}$ of a suspension of $\mathrm{L}$ $M$ cells (ATCC CCL-1.2; American Type Culture Collection, Rockville, MD, USA) $5 \times 10^{5}$ cells $/ \mathrm{ml}$ in
RPMI 1640 medium with fetal calf serum (FCS; Gibco Laboratories, Grand Island, NY, USA) $10 \%$ was placed in each well of a 96-well plate and cultured for $24 \mathrm{~h}$ to establish a monolayer. In parallel microculture plates, serial dilutions of test specimens were made in RPMI 1640 media containing actinomycin-D (Sigma) $10 \mu \mathrm{g} / \mathrm{ml}$ and incubated for $24 \mathrm{~h} ; 25 \mu \mathrm{l}$ of this solution were then transferred to plates with the L-M cells giving a final actinomycin-D concentration of $2 \mu \mathrm{g} / \mathrm{ml}$. After culture for a further $24 \mathrm{~h}$, viable cells adhering to the cultures plates were fixed with formaldehyde $2 \%$ and stained with crystal violet $0.2 \%$ solution at $25^{\circ} \mathrm{C}$ for $20 \mathrm{~min}$. The intensity of the stain was measured with a microplate reader (Titertek Multiskan MC; Flow Laboratories, Inc., McLean, VA) at $595 \mathrm{~nm}$. One unit of activity was defined as the dilution required to produce a $50 \%$ decrease in absorbance relative to control cells exposed to actinomycin-D alone.

IL-6 activity was determined by measuring in-vitro growth of an IL-6-dependent cell line MH60. BSF2. ${ }^{16}$ Briefly, cell suspensions $\left(1 \times 10^{4} / 175 \mu \mathrm{l}\right)$ were cultured with $25 \mu \mathrm{l}$ of serially diluted test specimens in RPMI 1640 with FCS $10 \%$ for $48 \mathrm{~h}$, then pulsed with $0.5 \mu \mathrm{Ci}$ (18.5 KBq) of [ $\left.{ }^{3} \mathrm{H}\right]$ thymidine (ICN 24070 ; ICN Radiochemicals, Irvine, CA, USA) during the last $6 \mathrm{~h}$ of incubation. Radioactivity incorporated by the cells was measured in a scintillation counter. IL-6 activity was standardised on the basis of a dose response curve obtained with rHuIL-6.

$T A F$ activity was determined by a conventional comitogenic assay with thymocytes from 3-5-week-old $\mathrm{C} 3 \mathrm{H} / \mathrm{HeJ}$ mice. Thymocytes $\left(1.5 \times 10^{6} / 175 \mu \mathrm{l}\right.$ of RPMI 1640 with FCS $10 \%$ ) were cultured with $25 \mu \mathrm{l}$ of test specimens in the presence of a submitogenic dose (final concentration, $1 \mu \mathrm{g} / \mathrm{ml}$ ) of phytohaemagglutinin (PHA: HA16, Wellcome Diagnostics, Dartford) for $72 \mathrm{~h}$. During the last $6 \mathrm{~h}$ of culture, the cells were pulsed with $0.5 \mu \mathrm{Ci}(18.5 \mathrm{KBq})$ of $\left[{ }^{3} \mathrm{H}\right]$ thymidine. The incorporated radioactivity was quantified in a scintillation counter. The results were expressed as the stimulation index (SI)-the ratio of the radioactivity in the test culture to that of the control culture (PHA alone).

All biological assays were performed three times in triplicate.

\section{Assays in vivo}

Groups of three $\mathrm{C} 3 \mathrm{H} / \mathrm{HeN}$ or $\mathrm{C} 3 \mathrm{H} / \mathrm{HeJ}$ mice $(6-12$ weeks old, male and female) were primed by an intravenous (i.v.) injection of $100 \mu \mathrm{g}$ of MDP $4 \mathrm{~h}$ before i.v. injection of M1Av $100 \mu \mathrm{g}$ or LPS from S. abortus-equi (Novo-Pyrexal) $0 \cdot 1 \mu \mathrm{g}$. Non-primed mice were also given M1Av $100 \mu \mathrm{g}$ or LPS $0 \cdot 1 \mu \mathrm{g}$. Blood was collected $90 \mathrm{~min}$ after injection of the test material and serum TNF and IL-6 levels were measured. The lethal toxicity for mice was determined according to the method of Galanos et al. ${ }^{17}$ Groups of four to six $\mathrm{C} 3 \mathrm{H} / \mathrm{HeN}$ or $\mathrm{C} 3 \mathrm{H} / \mathrm{HeJ}$ mice (8-12 weeks old, male and female) were sensitised by an i.p. 


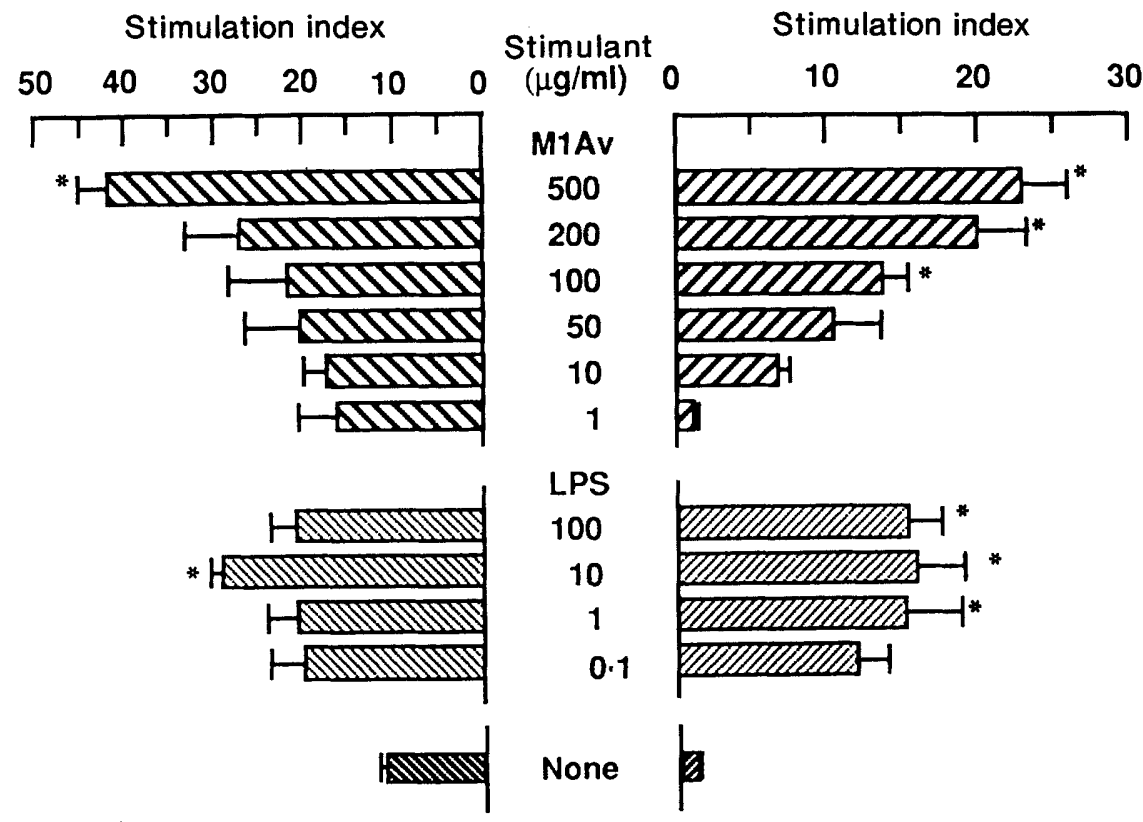

Cell-free (1in 20)

Cell-associated ( 1 in 80$)$

Fig. 1. TAF induction by $\mathrm{M} 1 \mathrm{Av}$ in $\mathrm{C} 3 \mathrm{H} / \mathrm{HeN}$ mouse macrophage cultures. Peritoneal macrophages from $\mathrm{C} 3 \mathrm{H} / \mathrm{HeN}$ mice were incubated with M1Av or $S$. abortus-equi LPS for $24 \mathrm{~h}$. Cell-free (diluted to 1 in 20 ) and cell-associated (1 in 80 ) samples were added to cultures of thymocytes $\left(1.5 \times 10^{6} / 200 \mu \mathrm{l} /\right.$ culture) from $\mathrm{C} 3 \mathrm{H} / \mathrm{HeJ}$ mice in the presence of PHA $1 \mu \mathrm{g} / \mathrm{ml}$. TAF activity (SI) was measured in triplicate. The control cultures with medium alone and with PHA alone resulted in 92 (SEM 28) and 236 (SEM 45) dpm, respectively. ${ }^{*}$ Indicates statistical differences between the control and test groups as determined by multiple comparisons.

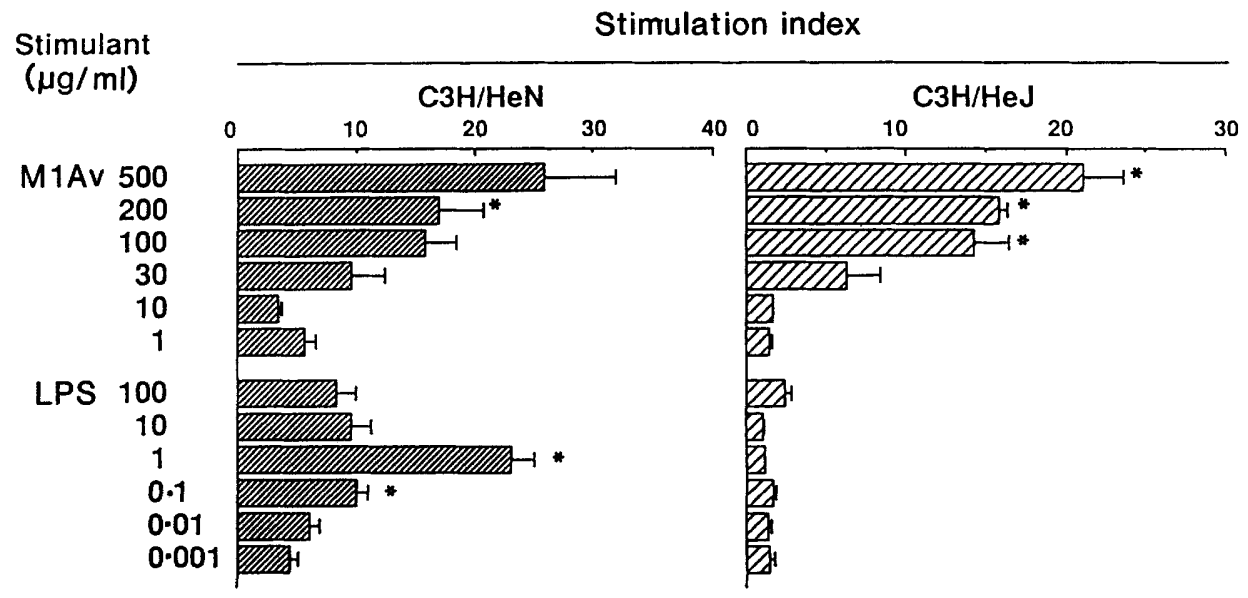

Fig. 2. Cell-associated TAF induction by M1Av and $S$. abortus-equi LPS in peritoneal macrophage cultures from $\mathrm{C} 3 \mathrm{H} / \mathrm{HeN}$ and $\mathrm{C} 3 \mathrm{H} / \mathrm{HeJ}$ mice.TAF activity of cell-associated specimens (diluted to 1 in 20) was measured in triplicate as described for fig. 1 . The amounts of radioactivity incorporated in control cultures with medium alone and with PHA alone were 310 (SEM 15) and 734 (SEM 65) dpm, respectively. The TAF activity (SI) of non-stimulated macrophage specimens from $\mathrm{C} 3 \mathrm{H} / \mathrm{HeN}$ and $\mathrm{C} 3 \mathrm{H} / \mathrm{HeJ}$ mice was 3.12 (SEM 0.22 ) and $1 \cdot 17$ (SEM 0.15), respectively.* Indicates statistical differences between the control and test groups as determined by multiple comparisons.

injection of galactosamine hydrochloride (Wako Pure Chemicals Co., Osaka, Japan) $18 \mathrm{mg}$ in $0.5 \mathrm{ml}$ of saline. Simultaneously, the mice were challenged by an i.v. injection of M1Av $(1,10$ or $100 \mu \mathrm{g})$ or LPS from E. coli O111:B4 (Difco) $(0 \cdot 01,0 \cdot 1,1$ or $10 \mathrm{ng}$ for $\mathrm{C} 3 \mathrm{H} / \mathrm{HeN}$ mice; $100 \mu \mathrm{g}$ for $\mathrm{C} 3 \mathrm{H} / \mathrm{HeJ}$ mice) in $0 \cdot 2 \mathrm{ml}$ of saline, and death was recorded for up to 3 days.

\section{Statistical analysis}

Data were analysed by the multiple comparison method. The $p$ values were corrected by Dunn's method. ${ }^{18}$

\section{Results}

When peritoneal macrophages from $\mathrm{C} 3 \mathrm{H} / \mathrm{HeN}$ mice were cultured in the presence of M1Av, cell-free and cell-associated TAF were induced in a dosedependent manner (fig. 1). In the case of LPS, a peak response was obtained at an LPS concentration of $10 \mu \mathrm{g} / \mathrm{ml}$, whereas with M1Av, the highest TAF levels were induced at the highest concentration $(500 \mu \mathrm{g} / \mathrm{ml})$ examined. The maximum cell-free and cell-associated TAF levels induced by M1Av were higher than those induced by $S$. abortus-equi LPS (at concentrations of $10 \mu \mathrm{g} / \mathrm{ml}$ ). Approximately 50 -fold more M1Av than 
TNF activity (U/ml)

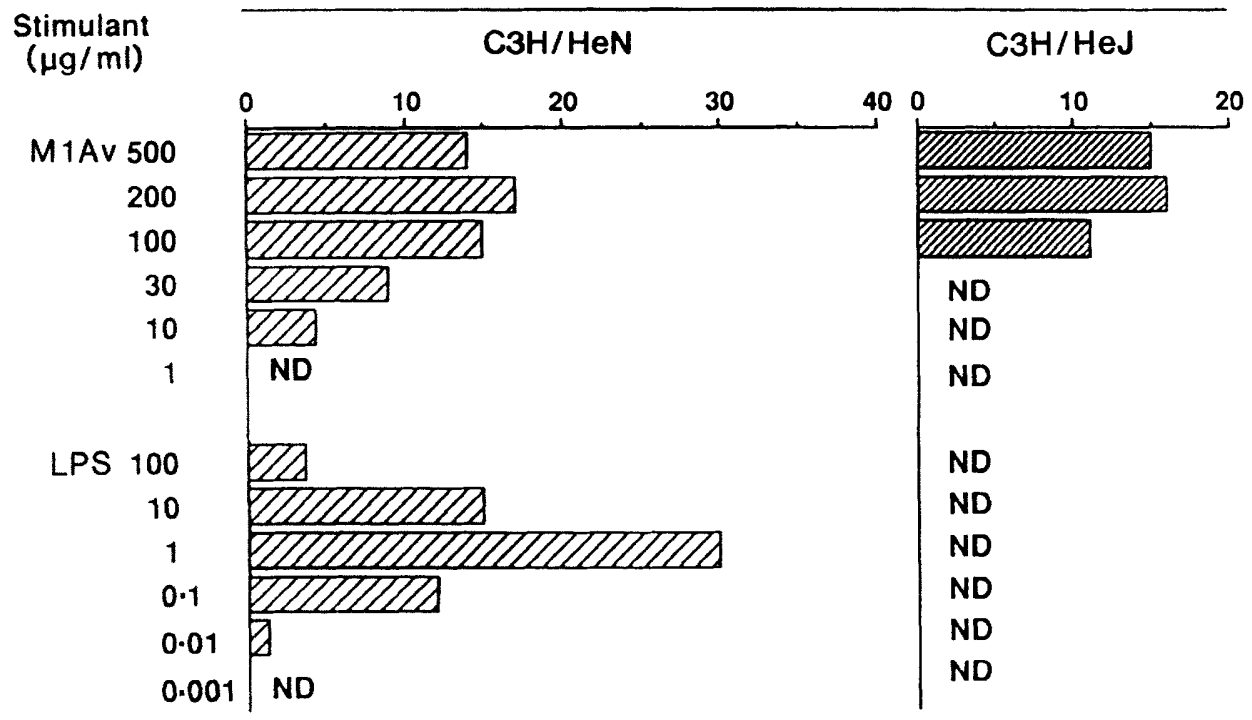

Fig. 3. TNF induction by M1Av and $S$. abortus-equi LPS in peritoneal macrophage cultures from $\mathrm{C} 3 \mathrm{H} / \mathrm{HeN}$ and $\mathrm{C} 3 \mathrm{H} / \mathrm{HeJ} \mathrm{mice}$. The cytotoxic activity of a series of diluted cell-free specimens was examined in actinomycin D-treated L-M cells. TNF activity was expressed as the test specimen dilution required to produce $50 \%$ cytocidal effects on target cells. Results represent means of triplicate assays. The standard error of TNF activity in each triplicate assay was $<10 \%$ of the respective mean value. ND, not detected.

Table I. IL-6 induction by M1 Av in $\mathrm{C} 3 \mathrm{H} / \mathrm{HeN}$ macrophage cultures

\begin{tabular}{|c|c|c|c|}
\hline \multirow{2}{*}{ Stimulant } & \multirow{2}{*}{$\begin{array}{c}\text { Concentration } \\
(\mu \mathrm{g} / \mathrm{ml})\end{array}$} & \multicolumn{2}{|c|}{ Mean IL-6 activity, U/ml (SEM) } \\
\hline & & Cell-free & Cell-associated \\
\hline \multirow[t]{7}{*}{ MIAv } & 500 & $3600(211)^{*}$ & $6.40(0.07)^{*}$ \\
\hline & 200 & $3600(146)^{*}$ & $6.56(0.18)^{*}$ \\
\hline & 100 & $1120(36)^{*}$ & $6.40(0.27)^{*}$ \\
\hline & 50 & $576(28)^{*}$ & $4.48(0 \cdot 11)^{*}$ \\
\hline & 20 & $144(7)^{*}$ & $2.72(0.02)^{*}$ \\
\hline & 10 & $44(2)^{*}$ & $1.36(0.02)^{*}$ \\
\hline & 1 & $10(0 \cdot 1)$ & $0.64(0.01)$ \\
\hline \multirow[t]{7}{*}{ LPS $\dagger$} & 100 & $656(6 \cdot 6)^{*}$ & $4.48(0.27)^{*}$ \\
\hline & 10 & $576(9 \cdot 1)^{*}$ & $4.96(0.20)^{*}$ \\
\hline & 1 & $464(14 \cdot 7)^{*}$ & $4.00(0 \cdot 11)^{*}$ \\
\hline & $0 \cdot 1$ & $560(18 \cdot 5)^{*}$ & $4 \cdot 16(0 \cdot 30)^{*}$ \\
\hline & $0 \cdot 01$ & $1120(16.5)^{*}$ & $8.00(0.09)^{*}$ \\
\hline & 0.001 & $61(1.4)^{*}$ & $3.52(0 \cdot 12)^{*}$ \\
\hline & 0.0001 & $9(0.6)$ & $0.66(0.04)$ \\
\hline None & & $9(0 \cdot 3)$ & $0.66(0.02)$ \\
\hline
\end{tabular}

*Significantly different from the respective control by the multiple comparison method

tLPS from S. abortus-equi (Novo-Pyrexal).

Table II. Serum TNF induction by M1Av and $S$. abortusequi LPS in MDP-primed and non-primed mice

\begin{tabular}{ccccc}
\hline \multicolumn{2}{c}{ Treatment } & & \multicolumn{2}{c}{ TNF activity, mean U/ml (SEM) } \\
\cline { 1 - 1 } $\begin{array}{c}\text { MDP } \\
\text { priming }\end{array}$ & $\begin{array}{c}\text { Inducing } \\
\text { injection (i.v.) }\end{array}$ & C3H/HeN & C3H/HeJ \\
\cline { 1 - 1 } No & MlAv & $7(2)$ & ND \\
Yes & MIAv & $153(22)^{*}$ & ND \\
No & LPS & $23(5)$ & ND \\
Yes & LPS & $195(35)^{*}$ & ND
\end{tabular}

ND, not detected.

*Significantly different from the respective control by multiple comparisons.
LPS was required to induce a similar level of TAF in macrophage cultures. M1Av also induced cell-free and cell-associated TAF in macrophage cultures from $\mathrm{C} 3 \mathrm{H} / \mathrm{HeJ}$ mice. However, S. abortus-equi LPS did not induce TAF in $\mathrm{C} 3 \mathrm{H} / \mathrm{HeJ}$ macrophage cultures (fig. 2). Furthermore, macrophages from $\mathrm{C} 3 \mathrm{H} / \mathrm{HeJ}$ as well as $\mathrm{C} 3 \mathrm{H} / \mathrm{HeN}$ mice released significant levels of TNF into the culture supernate after stimulation with $\mathrm{M} 1 \mathrm{Av}$ (fig. 3). In $\mathrm{C} 3 \mathrm{H} / \mathrm{HeN}$ mouse macrophages, the maximum response induced by $\mathrm{M} 1 \mathrm{Av}(200 \mu \mathrm{g} / \mathrm{ml})$ was lower than that induced by LPS $(1 \mu \mathrm{g} / \mathrm{ml})$, and the minimum effective concentration of M1Av was 100 1000 -fold higher than that of LPS. Macrophages of $\mathrm{C} 3 \mathrm{H} / \mathrm{HeJ}$ mice were less responsive to M1Av than those of $\mathrm{C} 3 \mathrm{H} / \mathrm{HeN}$ mice in terms of TNF production. M1Av also induced significantly higher levels of IL-6 in culture supernates than those induced by LPS in macrophage cultures from $\mathrm{C} 3 \mathrm{H} / \mathrm{HeN}$ mice (table I).

To examine the cytokine-inducing ability of M1Av in vivo, $\mathrm{M} 1 \mathrm{Av}(100 \mu \mathrm{g})$ was administered i.v. to $\mathrm{C} 3 \mathrm{H} / \mathrm{HeN}$ and $\mathrm{C} 3 \mathrm{H} / \mathrm{HeJ}$ mice, half of which were primed by i.v. injection with MDP $(100 \mu \mathrm{g}) 4 \mathrm{~h}$ before the challenge with M1Av or LPS. Both M1Av and $S$. abortus-equi LPS induced significantly increased levels of serum TNF in the MDP-primed $\mathrm{C} 3 \mathrm{H} / \mathrm{HeN}$ mice, whereas these stimulants did not induce it in $\mathrm{C} 3 \mathrm{H} / \mathrm{HeJ}$ mice irrespective of MDP priming (table II). In MDP-primed $\mathrm{C} 3 \mathrm{H} / \mathrm{HeN}$ mice elicited with either M1Av or LPS, markedly higher levels of IL-6 were released into the blood (table III).

Administration of a large amount of galactosamine i.v. sensitises mice to lethal toxicity of TNF, and M1Av was compared with $E$. coli LPS for its lethal toxicity in galactosamine-treated mice. M1Av $(10 \mu \mathrm{g})$ killed all $\mathrm{C} 3 \mathrm{H} / \mathrm{HeN}$ mice sensitised with galactosamine (table IV). The LD50 of M1Av was $3.16 \mu \mathrm{g} /$ 
Table III. Serum IL-6 induction by M1Av and LPS from $S$. abortus-equi in MDP-primed $\mathrm{C} 3 \mathrm{H} / \mathrm{HeN}$ mice

\begin{tabular}{cc}
\hline Preparations administered & $\begin{array}{c}\text { Serum IL-6 activity, } \\
\text { mean U/ml (SEM) }\end{array}$ \\
\hline M1Av alone & $679(59)$ \\
MDP-M1Av & $14458(1291)^{*}$ \\
MDP-LPS & $13417(2682)$
\end{tabular}

*Significantly different from the control group administered with MIAv alone by the multiple comparison method.

Table IV. Lethal toxicity of M1Av and $E$. coli O111:B4 LPS in galactosamine-loaded mice

\begin{tabular}{llrcc}
\hline $\begin{array}{c}\text { Strain of } \\
\text { mouse }\end{array}$ & Test material & $\begin{array}{c}\text { Dose } \\
(/ \text { mouse) }\end{array}$ & $\begin{array}{c}\text { Dead/ } \\
\text { tested }\end{array}$ & LD50 \\
\hline $\mathrm{C} 3 \mathrm{H} / \mathrm{HeN}$ & $\mathrm{M} 1 \mathrm{Av}$ & $10 \mu \mathrm{g}$ & $6 / 6$ & $3 \cdot 16 \mu \mathrm{g}$ \\
& $\mathrm{M} 1 \mathrm{Av}$ & $1 \mu \mathrm{g}$ & $0 / 6$ & $\ldots$ \\
& LPS & $10 \mathrm{ng}$ & $4 / 4$ & $0.75 \mathrm{ng}$ \\
& LPS & $1 \mathrm{ng}$ & $3 / 4$ & $\ldots$ \\
& LPS & $0.1 \mathrm{ng}$ & $2 / 4$ & $\ldots$ \\
$\mathrm{C} 3 \mathrm{H} / \mathrm{HeJ}$ & LPS & $0.01 \mathrm{ng}$ & $0 / 4$ & $\ldots$ \\
& M1Av & $100 \mu \mathrm{g}$ & $0 / 6$ & $>100 \mu \mathrm{g}$ \\
& LPS & $100 \mu \mathrm{g}$ & $0 / 4$ & $>100 \mu \mathrm{g}$ \\
\hline
\end{tabular}

mouse. This indicated that M1Av contained the equivalent of $0.046 \mathrm{ng}$ of LPS from $E$. coli O111:B4 based upon the Limulus test mentioned above. In this assay system, the LD50 for LPS from $E$. coli O111:B4 was $0.75 \mathrm{ng} /$ mouse, whereas up to $100 \mu \mathrm{g}$ of M1Av did not kill galactosamine-loaded $\mathrm{C} 3 \mathrm{H} / \mathrm{HeJ}$ mice.

To examine the possibility of a synergic effect of M1Av and LPS in inducing TNF, C3H/HeN mice primed with MDP (100 $\mu \mathrm{g})$ (three/group) were given S. abortus-equi LPS $(0 \cdot 1 \mu \mathrm{g}), \operatorname{M} 1 \operatorname{Av}(1 \mu \mathrm{g})$ or a mixture of the two compounds by i.v. injection. M1Av alone at this dosage did not induce a detectable serum level of TNF. The combination of M1Av and LPS induced higher levels of serum TNF than that induced by LPS alone but this was not significant.

\section{Discussion}

In this study we showed that M1Av, the carbohydrate-rich moiety from $A$. viscosus cell-wall-lysate, induced TNF, IL-6 and IL-1 in vivo and in vitro. We showed previously that M1Av exhibited species-specific antigenicity, powerful B cell mitogenicity, and polyclonal B cell activation. Cell-wall components that exhibited similar biological properties were also found amongst other oral Actinomyces strains, including a strain of $A$. viscosus isolated from human dental plaque and A. naeslundii ATCC 12104.11,12 Thus, several oral Actinomyces spp. may possess carbohydrate antigens that exhibit various immunobiological activities in vitro and in vivo. Since Actinomyces spp. are predominant in the dental plaque from sites with active gingivitis, ${ }^{1-3}$ their cell-wall carbohydrate antigen may induce excessive amounts of inflammatory cytokines in collaboration with LPS from the gram-negative anaerobic bacteria that appear in dental plaque during the development of gingivitis and periodontitis. The cytokines released locally might in turn induce inflammation in the periodontal tissues, with subsequent localised tissue destruction.

Oral and pyogenic streptococcal species also contain cell-wall carbohydrate antigens, and $\mathrm{M} 1$ antigens prepared similarly from purified streptococcal cell walls exhibit B cell mitogenicity and polyclonal B cell activation. ${ }^{19-21}$ Furthermore, Kimura et $a .^{22,23}$ reported that the M1 carbohydrate of mutans streptococci, when trinitrophenylated, is a novel T-cell independent type 2 antigen.

M1Av reportedly tags a portion of the peptidoglycan fragment, namely glutamic acid, alanine and ornithine in the molar ratio $2: 2: 1,{ }^{11}$ which is an atypical peptidoglycan peptide, unique to some Actinomyces spp. ${ }^{24}$ Peptidoglycan and MDP exhibit a wide variety of enhanced immunobiological responses. ${ }^{25}$ However, Nagao et al. ${ }^{26}$ claimed that peptidoglycan and MDP failed to induced IL-1 and TNF in murine macrophage cultures, which is contrary to the positive results with guinea-pig macrophages and human monocyte cultures. Controversy still exists as to the responsiveness of murine macrophages to peptidoglycan and MDP. Therefore, it is possible that a small portion of peptidoglycan residues tagged to the M1Av carbohydrate antigen may affect the responses in mice.

M1Av should have activated macrophages of LPSresistant $\mathrm{C} 3 \mathrm{H}-\mathrm{HeJ}$ mice to produce cytokines in vitro. However, it failed to induce TNF and IL-6 in MDPprimed $\mathrm{C} 3 \mathrm{H} / \mathrm{HeJ}$ mice, although positive tests were recorded in $\mathrm{C} 3 \mathrm{H} / \mathrm{HeN}$ mice. In accordance with these findings, M1Av killed galactosamine-loaded $\mathrm{C} 3 \mathrm{H} /$ $\mathrm{HeN}$, but not $\mathrm{C} 3 \mathrm{H} / \mathrm{HeJ}$ mice. Our calculations from the colorimetric Limulus test indicated that contamination by endotoxic substances in M1Av was low, which did not support the notion that the stimulative activities of M1Av were due to contaminating endotoxin. Similar findings have been reported with lipoteichoic acid (LTA-2) ${ }^{27}$ from Enterococcus hirae and an amphiphile ${ }^{28,29}$ from Mycobacterium bovis BCG. These preparations induced TNF and IL-6 in macrophage cultures from both $\mathrm{C} 3 \mathrm{H} / \mathrm{HeJ}$ and $\mathrm{C} 3 \mathrm{H} /$ $\mathrm{HeN}$ mice. However, they induced cytokines in MDPprimed $\mathrm{C} 3 \mathrm{H} / \mathrm{HeN}$, but not $\mathrm{C} 3 \mathrm{H} / \mathrm{HeJ}$ mice. ${ }^{30}$ Further studies will be required to elucidate the mechanisms of the different cytokine-inducing responses to nonendotoxic cell-wall substances in $\mathrm{C} 3 \mathrm{H} / \mathrm{HeN}$ and $\mathrm{C} 3 \mathrm{H} / \mathrm{HeJ}$ mice. 


\section{References}

1. Ellen RP. Oral colonization by gram-positive bacteria significant to periodontal disease. In: Genco RJ, Mergenhagen SE (eds) Host-parasite interactions in periodontal diseases. Washington DC, American Society for Microbiology. 1982: 98-111.

2. Ellen RP. Genus Actinomyces and other filamentous bacteria. In: Newman MG, Niesengard R (eds) Oral microbiology and immunology. Philadelphia, W B Saunders Co. 1988: 173-182.

3. Page RC. Gingivitis. J Clin Periodontal 1986; 13: 345-355.

4. Aukhil I, Lopatin DE, Syed SA, Morrison EC, Kowalski CJ. The effects of periodontal therapy on serum antibody (IgG) levels to plaque microorganisms. J Clin Periodontol $1988 ; 15$ : $544-550$.

5. Klausen B, Hougen HP, Fiehn N-E. Increased periodontal bone loss in temporarily B lymphocyte-deficient rats. $J$ Periodont Res 1989; 24: 384-390.

6. Chen P, Farrar JJ, Genco RJ. Immunological properties of Actinomyces viscosus: comparison of blastogenic and adjuvant activities. Infect Immun $1980 ; 28: 212-219$.

7. Clagett J, Engel D, Chi E. In vitro expression of immunoglobulin $\mathrm{M}$ and $\mathrm{G}$ subclasses by murine $\mathrm{B}$ lymphocytes in response to a polyclonal activator from Actinomyces. Infect Immun 1980; 29: 234-243.

8. Lopatin DE, Mangan DF, Horner IS. Cells involved in the mitogen-induced helper function which facilitates the blastogenic response to Actinomyces viscosus. Clin Immunol Immunopathol 1981; 19: 394405.

9. Metzger Z, Hoffeld JT, Charon J, Mergenhagen SE. Suppression of lymphocyte and fibroblast proliferation by Actinomyces viscosus-activated murine macrophages. $J$ Periodont Res $1987 ; 22$ : 456-460.

10. Gaegauf-Zollinger R, Burckhardt JJ, Gmür R, Guggenheim B Cell-mediated cytotoxicity against rat fibroblasts induced by Actinomyces viscosus. Infect Immun 1982; 37: 710-719.

11. Hamada S, Okahashi N, Kimura S et al. Novel antigens of oral Actinomyces species prepared from a cell wall enzyme lysate. Jpn J Med Sci Biol 1982; 35: 171-181.

12. Kimura $\mathrm{S}$, Hamada $\mathrm{S}$, Torii $\mathbf{M}$ et al. Lymphoid cell responses to bacterial cell wall components: murine B-cell responses to a purified cell wall moiety of Actinomyces. Scand J Immunol $1983 ; 17: 313-322$.

13. Tracey KJ, Cerami A. Cachectin/tumor necrosis factor and other cytokines in infectious disease. Curr Opin Immunol $1989 ; 1: 454-461$

14. Obayashi T, Tamura H, Tanaka S et al. A new chromogenic endotoxin-specific assay using recombined limulus coagulation enzymes and its clinical applications. Clin Chim Acta 1985: 149: $55-65$.

15. Galanos C, Lüderitz O, Westphal O. Preparation and properties of a standardized lipopolysaccharide from Salmonella abortus equi (Novo-Pyrexal). Zentralbl Bakteriol Hyg Abt 1 Orig A $1979 ; 243$ : 226-244.

16. Matsuda T, Hirano $T$, Kishimoto $T$. Establishment of an interleukin 6 (IL 6)/B cell stimulatory factor 2-dependent cell line and preparation of anti-IL 6 monoclonal antibodies. Eur J Immunol 1988; 18: 951-956.

17. Galanos C, Freudenberg MA, Reutter W. Galactosamineinduced sensitization to the lethal effects of endotoxin. Proc Natl Acad Sci USA 1979; 76: 5939-5943.

18. Dunn OJ. Multiple comparisons among means. J Am Statist Ass 1961; 56: 52-64.

19. Hamada S, McGhee JR, Kiyono H, Torii M, Michalek SM. Lymphoid cell responses to bacterial cell wall components: mitogenic responses of murine B cells to Streptococcus mutans carbohydrate antigens. $J$ Immunol 1981; 126: 2279-2283.

20. Torii M, McGhee JR, Koopman, WJ, Hamada S, Michalek SM. Lymphoid cell responses to bacterial cell wall components: polyclonal and immune responses of murine B cells to Streptococcus mutans carbohydrate antigens. $J$ Immunol 1981; 127: 2106-2112.

21. Morisaki I, Kimura S, Torii $\mathrm{M}$ et al. Cell wall preparation consisting of group A carbohydrate and peptidoglycan moieties from Streptococcus pyogenes activates murine B lymphocytes. Immunobiology 1985; 170: 293-304.

22. Kimura S, Kiyono $\mathrm{H}$, Beagley $\mathrm{KW}$ et al. Streptococcal serotype carbohydrate represents a novel class of type 2 antigen which is $\mathrm{T}$-independent. $J$ Immunol $1987 ; 138$ $4387-4394$

23. Kimura S, Kiyono H, Michalek SM, Hamada S, McGhee JR. Haptenated streptococcal antigens elicit either $\mathrm{T}$ celldependent type 1 or $\mathrm{T}$ cell-independent type 2 immune responses. Immunobiol 1987; 174: 146-161.

24. Schleifer KH, Kandler O. Peptidoglycan types of bacterial cell walls and their taxonomic implications. Bacteriol Rev 1972 36: 407-477

25. Takada H, Kotani S. Immunopharmacological activities of synthetic muramyl-peptides. In: Stewart-Tull DES, Davies $M$ (eds) Immunology of the bacterial cell envelope. Chichester, John Wiley and Sons Inc. 1985: 119-152.

26. Nagao S, Akagawa KS, Yamada K, Yagawa K, Tokunaga T, Kotani S. Lack of response of murine peritoneal macrophages to in vitro activation by muramyl dipeptide (MDP). I. Macrophage activation by MDP is species dependent. Microbiol Immunol 1990; 34: 323-335.

27. Tsutsui O, Kokeguchi S, Matsumura T, Kato K. Relationship of the chemical structure and immunobiological activities of lipoteichoic acid from Streptococcus faecalis (Enterococcus hirae) ATCC 9790. FEMS Microbiol Lett 1991; 76 : $211-218$

28. Ikeda-Fujita $T$, Kotani S, Tsujimoto $M$ et al. A novel immunomodulator derived from Mycobacterium bovis BCG which holds many bioactivities in common with endotoxins. Jpn J Bacteriol 1987; 42: 597-602.

29. Kotani S, Nagao A, Tamura T et al. Purification and endotoxinlike bioactivities of a novel amphiphile from $\mathrm{Myco}$ bacterium bovis BCG. In: Masihi KN, Lange W (eds) Immunotherapeutic prospects of infectious diseases. Berlin, Springer-Verlag. 1990: 19-36.

30. Takada H, Tamura M, Kawabata $\mathrm{Y}$ et al. Responses of $\mathrm{C} 3 \mathrm{H} / \mathrm{HeN}$ and $\mathrm{C} 3 \mathrm{H} / \mathrm{HeJ}$ mice to cytokine-inducing activities of bacterial components without endotoxicity. $J p n$ J Bacteriol 1992; 47: 202 